\title{
Disk battery ingestion: high clinic risk
}

\author{
Pasquale Di Pietro ${ }^{1 *}$, Silvia Vignola ${ }^{2}$, Salvatore Renna ${ }^{1}$, Emanuela Piccotti ${ }^{1}$, Arrigo Vittorio Barabino ${ }^{2}$ \\ From 71st Congress of the Italian Society of Pediatrics. Joint National Meeting SIP, SIMGePeD, Study Group \\ on Pediatric Ultrasoun, SUP Study Group on Hypertension \\ Rome, Italy. 4-6 June 2015
}

Over the last ten years disk battery (DB) ingestion have been increasing in children with serious consequences due to the diffusion of lithium battery (LB) that may cause catastrophic damages when lodged in the esophagus.

The severity of injury depends on cell type, size, voltage, location and time of contact with the mucosa because electrical generation of hydroxide ions at the negative pole, leakage of alkaline content in stomach and mechanical pressure.

Because LB are larger (> $20 \mathrm{~mm}$ ), flatter and have an higher voltage $(3 \mathrm{~V})$ than alkaline $\mathrm{DB}(1.5 \mathrm{~V})$ in small children their ingestion increases the risk of esophageal lodgment and tissue damage in just two hours [1,2].

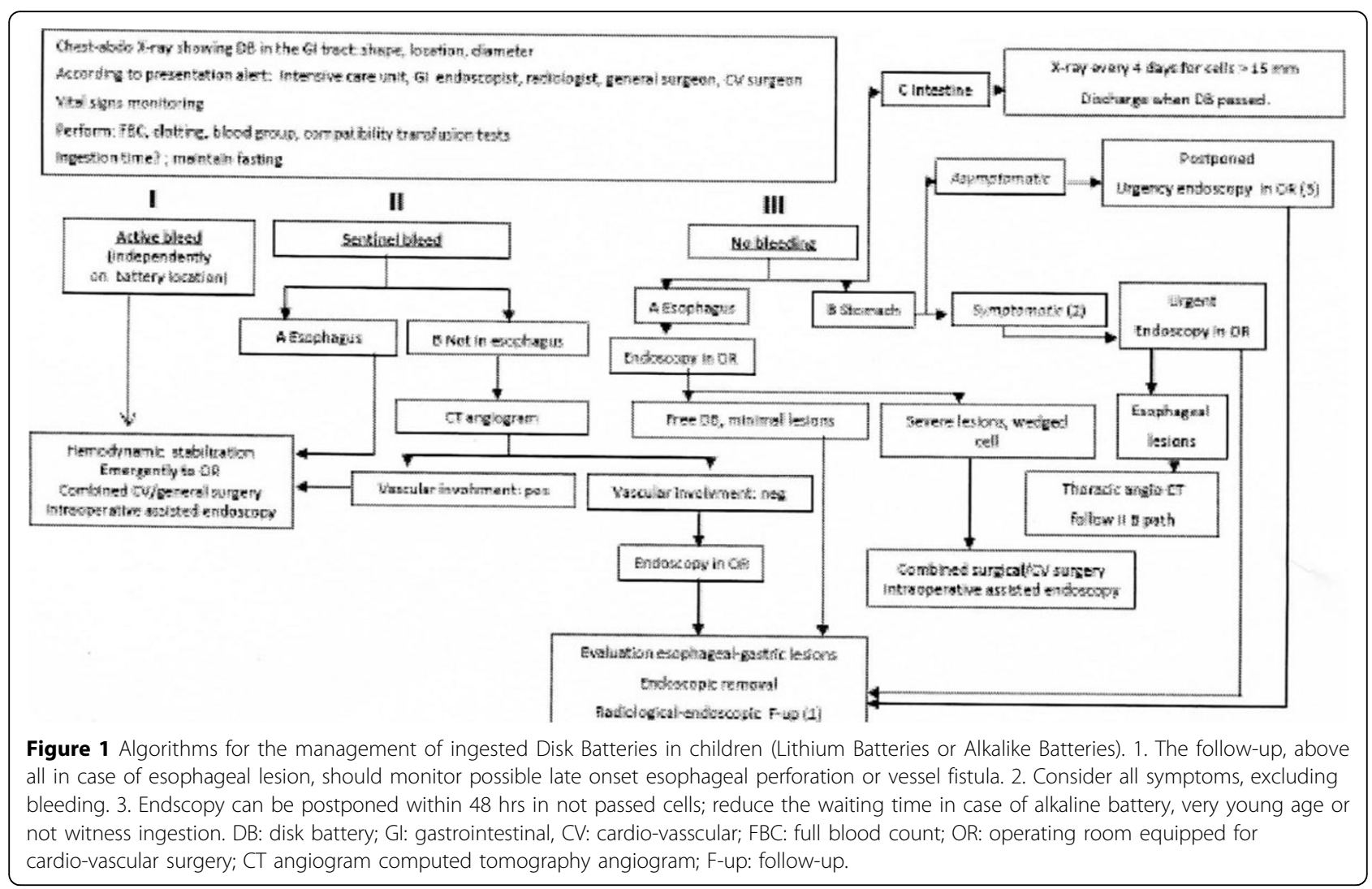

\footnotetext{
* Correspondence: pasqualedipietro@ospedale-gaslini.ge.it

'Emergency Medicine, G. Gaslini Istitute, Genoa 16147, Italy

Full list of author information is available at the end of the article
} 
DB ingestion is not witnessed in $92 \%$ of fatal outcomes and $56 \%$ of major complications; $36 \%$ of patients with esophageal lodgment are initially asymptomatic [3]. Clinical presentation can be variable from absence of symptoms to drooling, dysphagia, vomiting, chest pain, or dyspnea, fever, abdominal pain, irritability and feeding refusal and sudden fatal exsanguination for a fistula between esophagus and mediastinic vessels $[3,4]$. Other complications are trachea-esophageal fistula, laryngeal/ esophageal stenosis, esophageal perforation, vocal cord paralysis, tracheomalacia, aspiration pmeumonia, empyema, lung abscess, and spondylodiscitis [2]. Complications can be delayed, as the mucosal lesions may worsen also after DB removal. Plain chest and abdomen $\mathrm{X}$-ray have a primary role to address the diagnosis and locate DB, revealed by the double ring or "halo" effect.

A "sentinel bleed", isolated hematemesis/melena occurring hours or days before a fatal hemorrage, is another atypical presenting symptom [4]. Exsanguination can occur with the DB still in the GI tract or until 28 days after its removal $[1,2]$.

We propose a new protocol for DB ingestion management in children and stress the necessity of prevention with public awareness campaigns promoted by scientific Societies and preventive information addressed to parents and caregivers [3].

\section{Authors' details}

Emergency Medicine, G. Gaslini Istitute, Genoa 16147, Italy.

${ }^{2}$ Gastroenterology and Digestive Endoscopy Unit, G. Gaslini Istitute, Genoa

16147, Italy.

Published: 30 September 2015

\section{References}

1. National Capital Poison Center:, http://www.poison.org/battery/fatalcases. asp.

2. Litovitz T: Preventing battery ingestions: an analysis of 8648 cases. Pediatrics 2010, 125:1178-83.

3. Litovitz T: Emerging battery ingestion hazard: clinical implications. Pediatrics 2010, 125:1168-77.

4. Brumbaugh DE: Management of button battery-induced hemorrhage in children. J Pediatr Gastroenterol Nutr 2011, 52:585-9.

doi:10.1186/1824-7288-41-S2-A27

Cite this article as: Di Pietro et al:: Disk battery ingestion: high clinic risk. Italian Journal of Pediatrics 2015 41(Suppl 2):A27.

\section{Submit your next manuscript to BioMed Central} and take full advantage of:

- Convenient online submission

- Thorough peer review

- No space constraints or color figure charges

- Immediate publication on acceptance

- Inclusion in PubMed, CAS, Scopus and Google Scholar

- Research which is freely available for redistribution

Submit your manuscript at www.biomedcentral.com/submit
C Biomed Central 